Portland State University

PDXScholar

\title{
Women and Corrections: a Review of Oregon Prisoners' Perspectives on Procedural Justice
}

Kelci J. Mueller

Portland State University

Follow this and additional works at: https://pdxscholar.library.pdx.edu/honorstheses

Let us know how access to this document benefits you.

\section{Recommended Citation}

Mueller, Kelci J., "Women and Corrections: a Review of Oregon Prisoners' Perspectives on Procedural Justice" (2019). University Honors Theses. Paper 698.

https://doi.org/10.15760/honors.715

This Thesis is brought to you for free and open access. It has been accepted for inclusion in University Honors Theses by an authorized administrator of PDXScholar. Please contact us if we can make this document more accessible: pdxscholar@pdx.edu. 
Women and Corrections:

A Review of Oregon Prisoners' Perspectives on Procedural Justice

By

Kelci Mueller

An undergraduate honors thesis submitted in partial fulfillment of the requirements for degree of

Bachelor of Arts

in

University Honors

and

Criminology \& Criminal Justice

Thesis Advisor

Mark Leymon

Portland State University 


\section{Table of Contents}

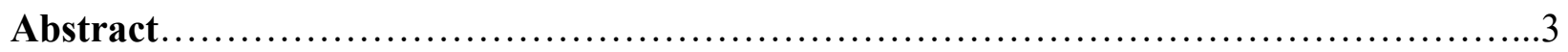

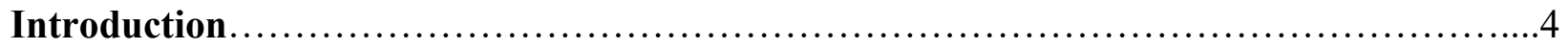

HerStory..............................................................4

Procedural Justice..........................................................4

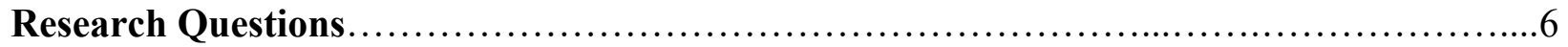

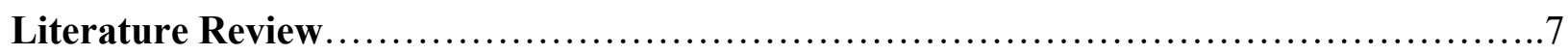

Police ...................................................................

Courts....................................................................... 8

Methods....................................................................... 12

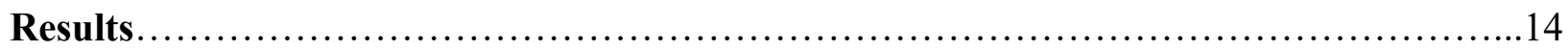

Before and During Arrest....................................................14

After Arrest..............................................................16

Pre-trial and Bail........................................................ 17

Defense Attorney........................................................ 19

Plea Deal...............................................................20

Sentence..............................................................21

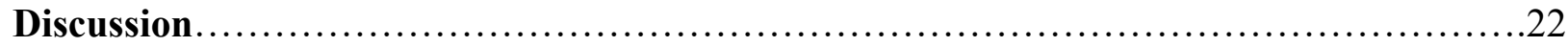

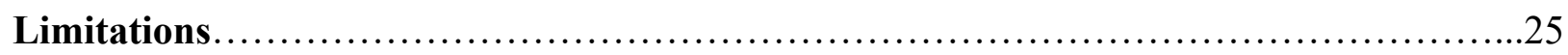

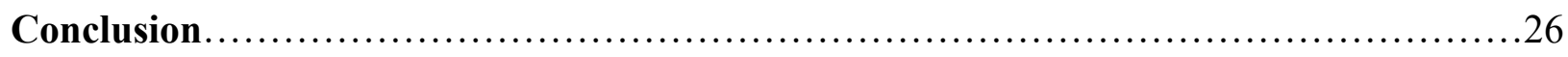

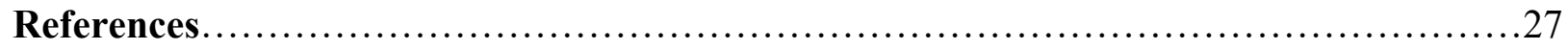




\begin{abstract}
This paper examines the perceptions of women prisoners in Oregon on procedurally just treatment and their attitudes of legitimacy towards agents of the criminal justice system. It argues that women in an Oregon prison perceived unjust treatment from criminal justice officials which leads to feelings of illegitimacy. 142 women from minimum and medium security at Coffee Creek Correctional Facility (CCCF) were surveyed about their interactions with police, defense attorneys, prosecutors, and judges. The research team analyzed survey responses to theoretically relevant questions such as when they were arrested, questioned by police, communicated with their defense attorney, plea bargain agreement, and sentencing. Evidence from the study showcases that there is a strong relationship between procedurally just treatment and legitimacy, particularly when the women reported experiencing unjust treatment; they were more likely to believe that their sentence was unfair or there was an error in their sentence. Since there is a lack of thorough research on procedural justice within the prisons and the courts in Oregon, specifically among women, the paper recommends that there needs to be further inquiry on police and courts treatment towards offenders.
\end{abstract}




\section{Introduction}

\section{HerStory}

The research presented in this paper is from exploratory research that was gathered by the Oregon Justice Resource Center's Women's Justice Project in collaboration with Portland State University's Department of Criminology and Criminal Justice. The purpose of the research was to allow women to share their experiences within Oregon's criminal justice system, to fill gaps in the research surrounding women prisoner's in Oregon, and affect policy and law. The team of researchers went into Coffee Creek Correctional Facility (CCCF) in Wilsonville, Oregon and interviewed 142 women in minimum and medium security. This article will analyze the first part of the two part survey which has questions that range from their experience with the legal system (including police officers, prosecutors, defense attorneys, and judges), their recent criminal case, the relationships with their partners, and the process as a whole from arrest to sentencing.

\section{Procedural Justice}

Procedural justice is a theoretical framework first developed by Thibaut and Walker, they suggest that the people's perceptions are dependent on the favorability of the outcome. This means that when there is a good outcome, they are more likely to find the system legitimate and vice versa. They are proposing that if the respondent feels in control of their situation, "they believe that the procedure is fair; where they feel they lack control they believe it is unfair." (Tyler, 1990). From Thibaut and Walker's perspective, Tom Tyler extends this research by suggesting that control isn't the factor that persuades a respondent to feel as though the process is fair and legitimate. 
Tyler argues that if the system is regarded as legitimate, people will obey the laws whether there is a chance of punishment. An example is that some people might use drugs because they don't find it morally apprehensible, however they won't steal because they regard that as a legitimate crime set by the legal system's standards. And this of course is "regardless of the potential for punishment. (Tyler, 1990).

Tyler suggests that procedural justice isn't about morality but legitimacy. "'Legitimacy” (that is, people's perception as to whether law enforcement officials rightly have authority over them)" (Bottoms \& Tankebe, 2012) or "the right to rule and the recognition by the ruled of that right (Sternberger, 1968; Beetham, 1991; Coicaud, 2002; Tyler, 2006a; Bottoms and Tankebe, in press)" (Jackson, Hough, Bradford, Quinton, 2012, p. 2). Legitimacy is needed for social institutions to run effectively, especially the police and courts because the people who are being subjected to policing (arrest, charged, and convicted) need to view the police as "right and proper" (Jackson, Hough, Bradford, Quinton, 2012, p. 2).

Procedural justice is a thoroughly researched topic of interest for decades. However, in Oregon, there has been little to no research done regarding procedural justice. With the studied carried out in CCCF on the women prisoners, it will hopefully shed light on the problems regarding the courts and polices treatment towards women offenders. It should be noted that there is a limitation on the research because of the population selected that it will be from the women prisoner's perspectives. Women experience things different than men and prisoners will have experience that will be unique but also different. 


\section{Research Questions}

Using Tom Tyler's definition of procedural justice, the survey responses from Coffee Creek Correctional Facility will be analyzed to answer a few key things about procedural justice in Oregon. The first question that this article is going to answer is do women prisoners in Coffee Creek Correctional Facility in Oregon experience feelings of unfairness/unjust treatment by the police and/or the courts? And then the next question that will be answered is there a lack of procedural justice in Oregon courts? The main goal is to determine whether there needs to be further inquiry into this topic here in Oregon. 


\section{Literature Review}

From arrest to charges and then to either trial or plea bargaining, the process of the criminal justice system is important in determining whether an offender is likely to recidivate. Unfairness and misunderstanding can happen at all levels of interaction between potential suspects and members of the criminal justice system. With the initial arrest, there is interaction with the police. Then once processed, the defendants have a right to a lawyer, the defense attorney. After their interaction with the defense attorney, prosecutors and judges get involved. This can lead to a lead plea or they go to trial. At every stop along the way to prison, defendants interact with different members of the system, and with each different member, there is a possibility of mistreatment. Defendants face many actors of the criminal justice system that can influence their perceptions of legitimacy.

\section{Police}

Police brutality is a major topic being researched today. Racial profiling and excessive use of force are two key examples of how mistreatment can start in the criminal justice system before Miranda rights are read. According to an annual review by Daniel Nagin and Cody Telep there is a strong association between feelings of legitimacy towards police and procedurally just treatment among offenders and delinquents. (Nagin \& Telep 2017; Piquero et al. 2005; White et al. 2016). Furthermore, the studies suggest that there is a connection between procedurally just treatment and trust in the police when looking at different populations such as MuslimAmericans, Australians, Israeli, and students in Jamaica (Nagin \& Telep 2017). However, Nagin \& Telep go on to suggest that even though there is a strong connection between procedurally just treatment by the police and legitimacy, they are skeptical to say that there is causation. Another study by Jackson, Hough, Bradford, and Quinton (2012) also find similar evidence between 
legitimacy in the police and fair treatment, "Is there evidence for instrumental motivations to comply with the law... the answer is no." They relay that there is no connection between fair treatment and compliance with the law when interaction with police officials.

There is a saying that not all police are bad and like any other job anywhere else, there are going to be some employees who break and bend the rules making them not very effective workers. However, the difference here is that their actions directly affect the lives of other people. An ineffective police officer is one who uses excessive force, who breaks the procedural laws in order to make an arrest, and who defies the constitutional rights afforded to the citizens. "However, if in time it becomes clear that the power-holder is routinely using power to engage in corrupt practices, it is very like that the public's recognition of his or her right to rule will be gradually withdrawn" (Bottoms \& Tankebe, 2012). The further the police break or bend the rules, the less the citizens are going to trust and legitimize their right to rule over them.

In Oregon, Renauer \& Covelli (2011) examined whether there was feelings of less legitimacy and biased toward the police based on racial discrimination. It was found that there was a correlation between racial discrimination (procedurally unjust treatment) and feelings of legitimacy here in Oregon. When looking at factors of mental health, race, and police contact, Thompson \& Kahn (2016) found that in Oregon people who have mental health issues are less likely to trust the police. However, there are no studies in Oregon that directly link the correlation of procedurally just treatment of women offenders and legitimacy in the police. The paper is hoping to fill the gap about women prisoners and their perceptions of police legitimacy. 


\section{Courts}

\section{Prosecutors}

Prosecutors play a vital role in the criminal justice system. They can use their discretion to take someone to trial or offer them a plea deal. They have the power and ability to decide the defendant's fate. This is important because if the defendant is given an unfair charge, it is the prosecutors who decided that. According to The Problems With Prosecutors by David Sklansky (2018) “prosecutors' professional decisions are relatively unconstrained and subject to weak oversight: discussions of power overlap with discussions of discretion and accountability." Because of the lack of oversight and accountability there is a possibility of mistreatment by the prosecution and that can affect the defendant's view of legitimacy in the criminal justice system.

The discretion prosecutors have allowed them the ability to have the power to charge what they want to charge; this leaves room for inconsistent punishment. It doesn't allow for uniformity within the courts and often leaves feelings of unfairness because one defendant may be punished less severely then another for the same criminal act. Additionally, in efforts to allow the defense a fairer opportunity to defend, they are required by law to turn over certain materials to the defense under "brady laws". In one study 2,012 cases over a 30-year period were reviewed that showed evidence of prosecutorial wrongdoing (Sklansky, 2018; Weinburg 2003). In another study "707 cases involving 782 judicial findings of prosecutorial misconduct, which works out to 59 cases per year, involving 65 violations. Sixty-six of the 782 findings of prosecutorial misconduct involved Brady violations" (Sklanskly, 2018; Ridolfi \& Possley, 2010). Misconduct and mistreatment can lead to less legitimacy because if the prosecutors are punishing defendants illegally, then they are not going to think their sentence is fair. 


\section{Defense Attorneys}

Due to the power of the prosecutor's discretionary decisions, it does not leave a lot of room for defense attorneys to give their defendant the most appropriate punishment possible. Plea bargains allow the prosecution to avoid trial and take control of what happens to the defendant without the influence of a judge. Additionally, with public defenders making up most lawyers defending and their large case load, it is difficult for a proper defense. First, the lack of time spent on each case, defense attorneys are unable to explain what is going on and negotiate due to tight schedules. Second, plea bargains allow the possibility of not spending time going to trial, therefore many defense attorneys would rather avoid going to trial because of a good deal offered on the table, regardless if the defendant is guilty or not. Typically in low income areas, criminal defense attorneys have high caseloads which restricts the amount of time they can have with each individual client (Bruce Green, 2003).

If there is a lot of limitations to what the defense attorneys can do for their clients and there is a limitation on time, this can make the defendant feel unfair with their treatment by the defense attorneys, which can cause them to feel as though the system is not legitimate if it cannot give them accurate representation. Although this research is thoroughly studied throughout the United States, the lack of studies in Oregon about defense attorney treatment and feelings of unfairness leads to needing more research into whether or not defense attorneys need to be reevaluated when it comes to time spent on each case and overall treatment towards the defendants. 


\section{Judges}

Judges are viewed as a role model in the courts. They are wise, experienced, and unbiased. The equilibrium scale presented for the symbol of courts, the balanced between justice and fairness; taking each side into consideration and finding the best balance for the both. "The judge emphasizes problem-solving over blame, and gives encouragement and praise for their efforts." (Wales, Hiday, \& Ray, 2010). Unlike the prosecutors and defense attorneys, they do not take a side, they sentence to the best of their ability, and they make sure that there is procedural justice.

In a study that examined the relationship between procedural justice and judges in a mental health court, it was found that there was strong correlation between fairness in the process and judges' treatment (Wales, Hiday, \& Ray, 2010). A similar study in 2002 in mental health courts involving judges and procedural justice found that if the defendant was treated with respect and felt they had a voice in the court room, they were more likely to have strong feelings of procedural justice when compared to a traditional court (Poythress, Petrila, McGaha, \& Boothroyd, 2002). These studies show if the judge treats the defendant with respect, allows their voice heard, and sentences them using unbiased opinion, that there will be feelings of fairness from the defendants. 


\section{Methods}

A two-part survey was conducted in collaboration with the Oregon Justice Resource Center's Women's Justice Project, the Criminology and Criminal Justice Department at Portland State University, and Coffee Creek Correctional Facility (CCCF) in the winter of 2017 to the spring of 2018. Both parts of the survey were in group setting, in a classroom with pencil and paper, and the target population was women prisoners at CCCF in minimum and medium security. The first part of the survey had 142 women that were divided into two groups. Additionally, the surveys in the first part were separated by if the women had a trial or if the women did not have a trial. The second part of the survey had 66 women participate and it was a single group. The surveys were written as exploratory research and there weren't any expectations of outcomes of the answers. The survey asked questions regarding the criminal justice system (from arrest to prosecution to intake), about their lives in prison (programs, medical care, mental health care), and then about their lives before and future lives (i.e childhood history, relationship history, and future plans).

Table 1.1: Demographics

\begin{tabular}{|c|c|c|c|c|c|}
\hline \multicolumn{2}{|c|}{ RACE } & \multicolumn{2}{c|}{ MARITAL STATUS } & \multicolumn{2}{c|}{ SEXUAL ORIENTATION } \\
\hline White & $69.01 \%$ & Single & $45.07 \%$ & Heterosexual & $79.58 \%$ \\
Black & $7.04 \%$ & Married & $17.61 \%$ & Homosexual & $5.63 \%$ \\
LatinX & $5.63 \%$ & Domestic Partner & $7.04 \%$ & Bisexual & $13.38 \%$ \\
Native American & $4.23 \%$ & Divorced & $26.76 \%$ & Something Else & $1.41 \%$ \\
Asian American & $0.70 \%$ & Widowed & $3.52 \%$ & & \\
Pacific Islander & $11.97 \%$ & & & & \\
Other & $1.41 \%$ & & & & \\
\hline
\end{tabular}

Of the 142 women interviewed at CCCF, $69.01 \%$ were white, $11.97 \%$ were Pacific Islander, and 7.04\% were black. Compared to the state's white make up 87.1\%, Pacific Islanders (0.4\%), and blacks make up 2.2\% (United States Census Bureau). Most of the women were 
single (45.07\%), followed by Divorced at 26.76\%, and then married (17.61\%). The women state they are heterosexual the most often $(79.58 \%)$ and then bisexual at $13.38 \%$. The average age of the women at CCCF was 35.71 with the oldest being 75 and the youngest 18 .

This paper will examine the first-part to the survey to answer the research questions since the first part is about their time in the criminal justice system while the second part is about what their future is going to be like. There will be use of cross tabulation amongst the quantitative questions to determine if there is a relationship between key questions (Do you think you sentence was fair?, Is/was there an error in your sentence/judgement, Did your attorney explain what was happening in your case in a way that you could understand?, etc.) and other quantitation questions within the survey. Using crosstabulation with the p-values of less than or equal to $.01 ; .05 ; .10$ to determine the strength of the relationship and will be used to explain why their relationship is important. 


\section{Results}

\section{Before and During Arrest}

Table 2.1: Housing

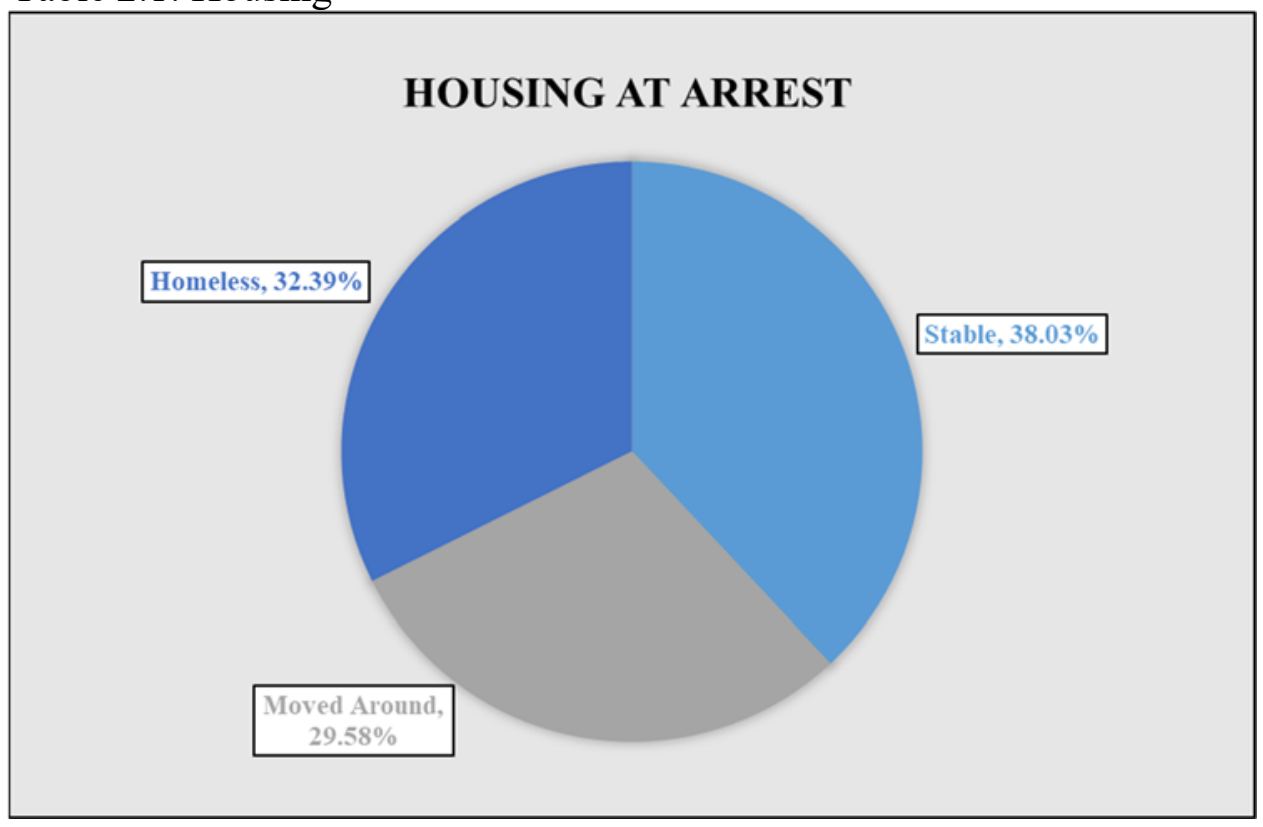

Table 2.1 shows that the women had stable housing (they had a permanent residency, didn't move around, owned a house, or rented an apartment) with $38.03 \%$. The next largest percentage $32.39 \%$ reported being homeless at the time of arrest and the last group reported moving around a lot $(29.58 \%)$.

Table 2.2: Parole \& Probation

\begin{tabular}{|c|c|c|c|c|}
\hline \multicolumn{3}{|c|}{ PAROLE \& PROBATION } \\
\hline \multicolumn{2}{|c|}{ Parole at Arrest } & & \multicolumn{2}{c|}{ Probation at Arrest } \\
\cline { 1 - 1 } Yes & $17.99 \%$ & & Yes & $32.37 \%$ \\
No & $82.01 \%$ & & No & $67.63 \%$ \\
\hline \multicolumn{2}{|c|}{ Understand the Terms } & & Understand the Terms \\
\cline { 1 - 1 } Yes & $76.67 \%$ & & Yes & $75.00 \%$ \\
No & $20.00 \%$ & & No & $22.73 \%$ \\
N/A & $3.33 \%$ & & N/A & $2.27 \%$ \\
\hline
\end{tabular}


Table 2.2 showcases $17.99 \%$ were on parole when they were arrested and $32.37 \%$ were on probation. The question asked did you understand the terms of your PPS? (Parole/post-prison supervision) and $20.00 \%$ said no while $76.67 \%$ said yes (3.33\% didn't answer). The same question was asked for probation and $22.73 \%$ said no while $75.00 \%$ said yes $(2.27 \%$ didn't answer).

Table 2.3: Time of Arrest

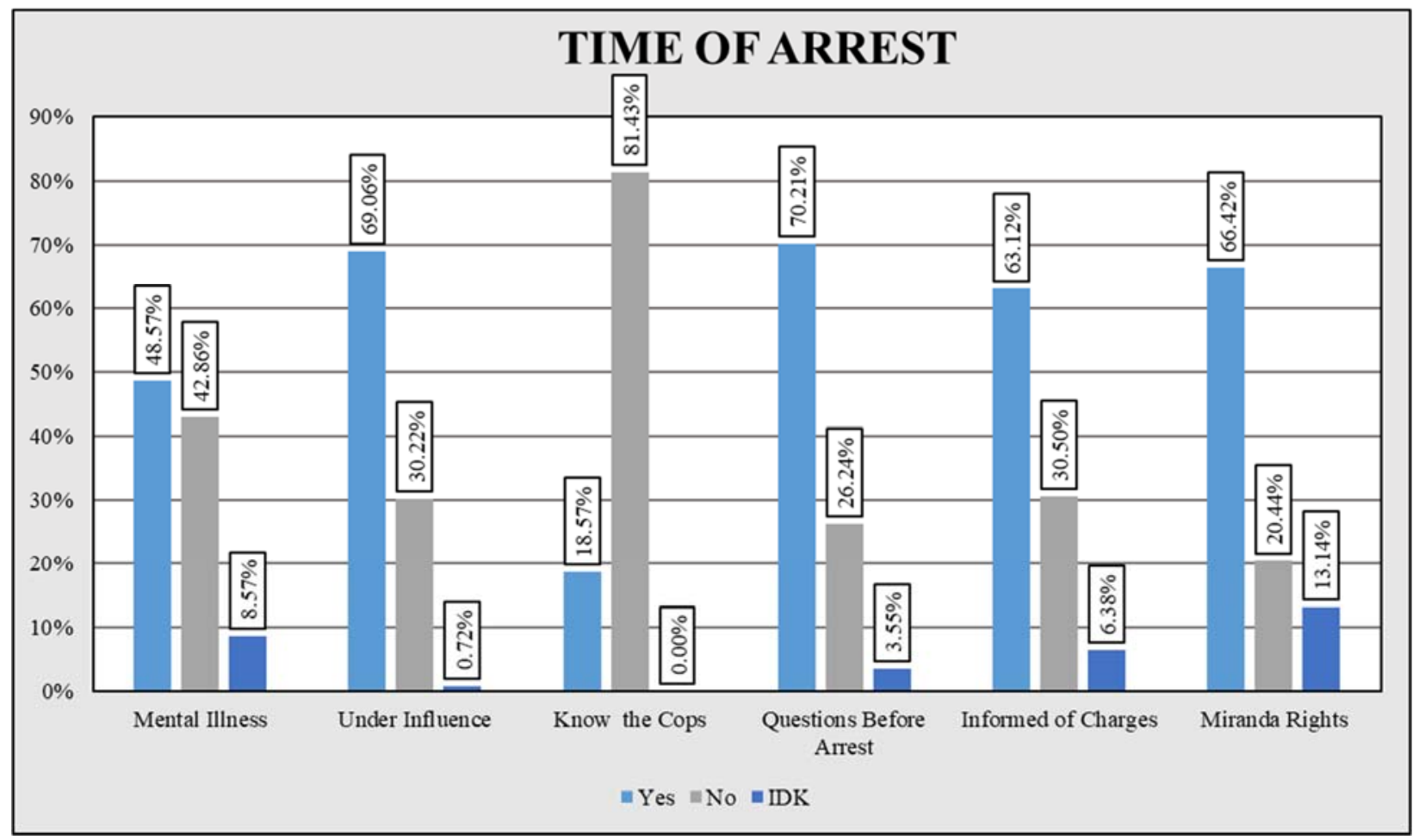

The women were asked questions about the time of their arrest. The graph shows the different questions that were ask and their percentages of responses of yes, no, and IDK (I don't know). The first question was were you experiencing symptoms of a mental illness at the time of your arrest? The women's majority response was yes at $48.57 \%$, followed by no at $41.86 \%$, the rest didn't know if they were experiencing any symptoms of mental illness $(8.57 \%)$. The next questioned ask were you under the influence of drugs/alcohol at the time of your arrest? More 
than two-thirds $(69.06 \%)$ reported being under the influence, $30.22 \%$ were not under the influence, the rest did not know $(0.72 \%)$.

Following the questions about mental illness and drugs/alcohol, the next question asked did you personally know the cops who arrested you?, most of the respondents answer no (81.43\%), with only $18.57 \%$ answered yes. Did the cops ask you questions BEFORE you were arrested? $70.21 \%$ reported yes, $26.24 \%$ said no, and 3.55\% don't know. Did the cops tell you about why they were arresting you? A surprisingly high number reports $30.50 \%$ were not informed of their charges, but the majority $(63.12 \%)$ were, the rest didn't know. The last question on the graph asks did the cops tell you about your Miranda rights (i.e. right to remain silent, right to an attorney)?, the majority response was yes $(66.42 \%)$, followed by no they were not told about their rights (20.44\%) and 13.14 did not know about their rights.

\section{After Arrest}

Table 3.1: After Arrest

\begin{tabular}{|c|c|c|c|}
\hline \multicolumn{4}{|c|}{ AFTER ARREST } \\
\hline & Yes & No & IDK \\
\hline Asked for Attorney & $43.97 \%$ & $43.97 \%$ & $12.06 \%$ \\
\hline Questions After Arrest & $71.63 \%$ & $24.11 \%$ & $4.26 \%$ \\
\hline Talk to Cops & $60.99 \%$ & $32.62 \%$ & $6.38 \%$ \\
\hline Recorded the Talk & $34.82 \%$ & $35.71 \%$ & $29.46 \%$ \\
\hline Forced to Talk & $35.96 \%$ & $53.51 \%$ & $10.53 \%$ \\
\hline Write for Cops & $2.13 \%$ & $93.62 \%$ & $4.26 \%$ \\
\hline Attorney During Writing & $1.75 \%$ & $92.98 \%$ & $5.26 \%$ \\
\hline Forced to Write & $6.12 \%$ & $87.76 \%$ & $6.12 \%$ \\
\hline Know the Cops & $21.95 \%$ & $75.61 \%$ & $2.44 \%$ \\
\hline Personal Information & $30.71 \%$ & $57.14 \%$ & $12.14 \%$ \\
\hline Under the Influence* & $63.50 \%$ & $33.58 \%$ & $2.19 \%$ \\
\hline $\begin{array}{l}\text { Mental Health } \\
\text { *4 no responses; two responses of yes \& no; } \\
\text { one response that says "Coming off heavy met }\end{array}$ & $53.49 \%$ & $40.31 \%$ & $6.20 \%$ \\
\hline
\end{tabular}


The next section relays information about what happened after the respondents were arrested. The first questioned asked was did you ask for an attorney? 43.97\% of respondents said yes and no, while $12.06 \%$ said they didn't know. Did the cops ask you questions? $71.63 \%$ were asked questions by the police after they were arrested, $24.11 \%$ were not asked questions, and 4.26\% didn't know. Was an attorney with you? (When writing for the police), $92.98 \%$ said no an attorney was not present (1.75\% said yes and 5.26\% said I don't know). Did the cops use any personal information about your family/children to encourage you to talk? The majority said no (57.14\%), 30.71\% said yes and $12.14 \%$ said I don't know. When asked if they were under the influence of drugs or alcohol during questioning after arrest $63.50 \%$ said yes, $33.58 \%$ said no, 2.19\% said I don't know, two responded yes and no, and one response that said "Coming off heavy meth use." Finally, 53.49 answered yes that they were experiencing symptoms of mental illness during questioning, 40.31\% said no, and 6.20\% said they didn't know.

\section{Pretrial and Bail}

Table 4.1: Pretrial

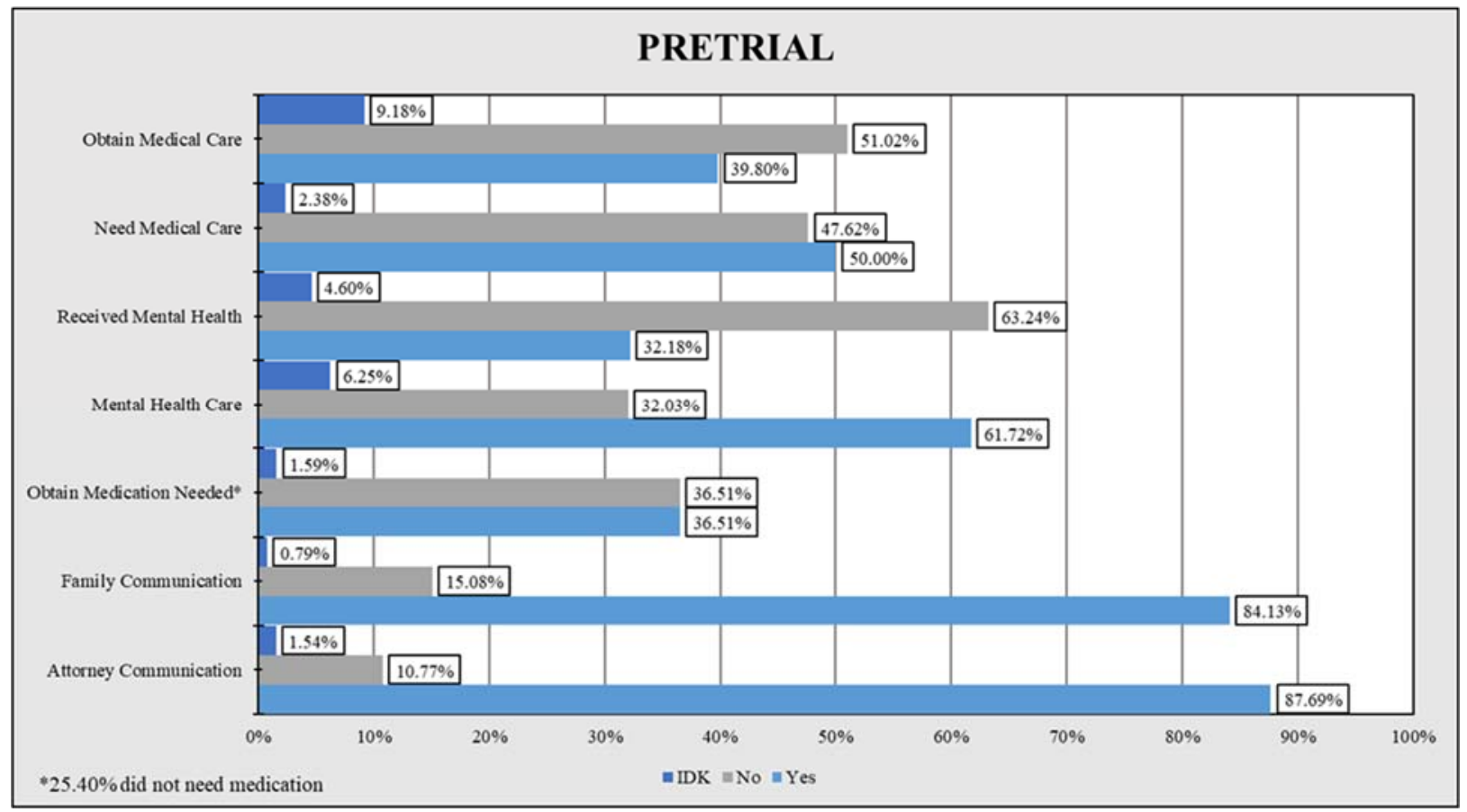


Before entering a plea bargain, an Alford plea, a plea of no contest, or a trial the respondents were asked a series of questions related to their time in the criminal justice system. The average time spent in jail pretrial/plea bargain was 123.06 days with a standard deviation of 139.20. The maximum amount of days spent was 730 (2 years) and the minimum was 1 day before. When asked if they were able to communicate with their attorney $87.69 \%$ said yes while $10.77 \%$ said no, and $1.54 \%$ said I don't know. The next question was communication with friends/family during their time in jail and $84.13 \%$ said yes, $15.08 \%$ said no, and $0.79 \%$ said they didn't know.

There was a slight majority that said they needed medical care, however, 51.02\% responded they did not receive medical care. After removing the $25.40 \%$ that did not need medication while in jail, the same percentage of respondents said yes and no $(36.51 \%)$ to the question if they received the medication they needed in jail, while $1.59 \%$ said they didn't know. The majority of the respondents answered that they needed mental health care $(61.72 \%)$ yet the majority responded they did not receive mental health care $(63.24 \%)$.

The respondents were asked questions about bail. The average amount of time between the respondent's time of arrest and release hearing is 53.77 with a standard deviation of 101.11. The maximum time spent was 370 days (1.01 years) and the minimum time was 0 days. $31.30 \%$ were released on bail, $66.41 \%$ were released on conditional terms, $1.53 \%$ were released with their own recognizance, and 0.76 answered that they didn't know. The majority stated they didn't violate their terms of release $(65.62 \%)$ while $29.17 \%$ did violate the terms of their release. The average bail amount was $\$ 3,968.75$ with a standard deviation of $\$ 6,309.96$. The maximum amount of bail set was $\$ 25,000$ and the minimum was $\$ 0$. The majority did not have additional 
fees to posting bail (47.37\%). Additionally, the majority did not receive the bail back after trial $(57.14 \%)$.

\section{Defense Attorney}

Table 5.1: Defense Attorney Type

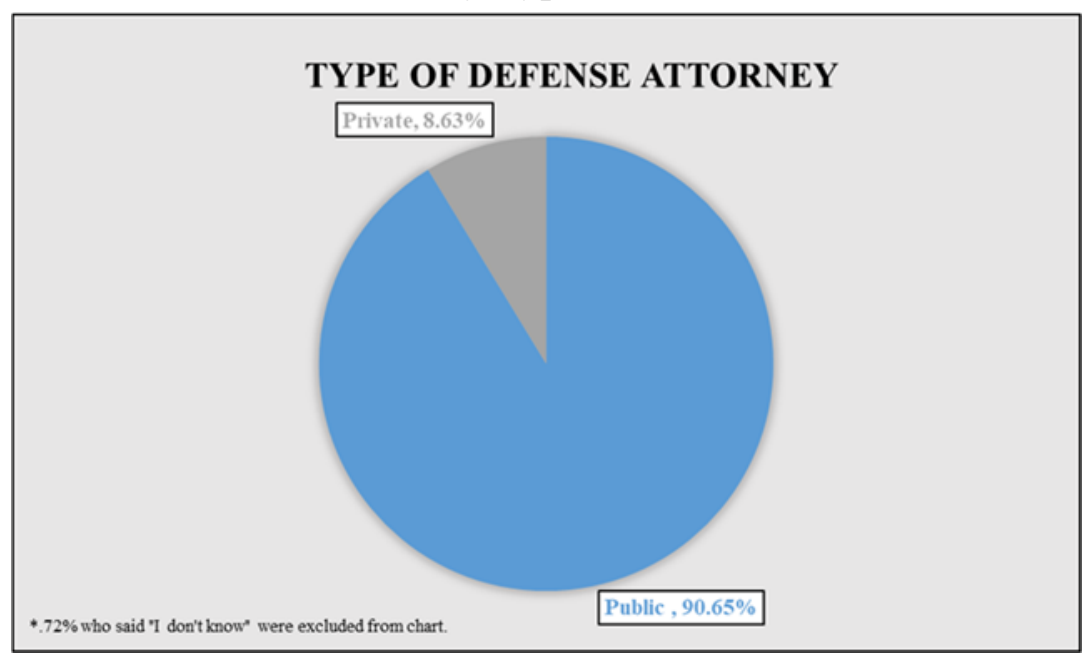

As shown on Table 5.1, the respondents answered questions about their criminal defense attorney, the first questioned they answered was How did you get your attorney? 90.65\% obtained a court appointed/public defender while only $8.63 \%$ received a private/retained

Table 5.2: Defense Attorney Treatment

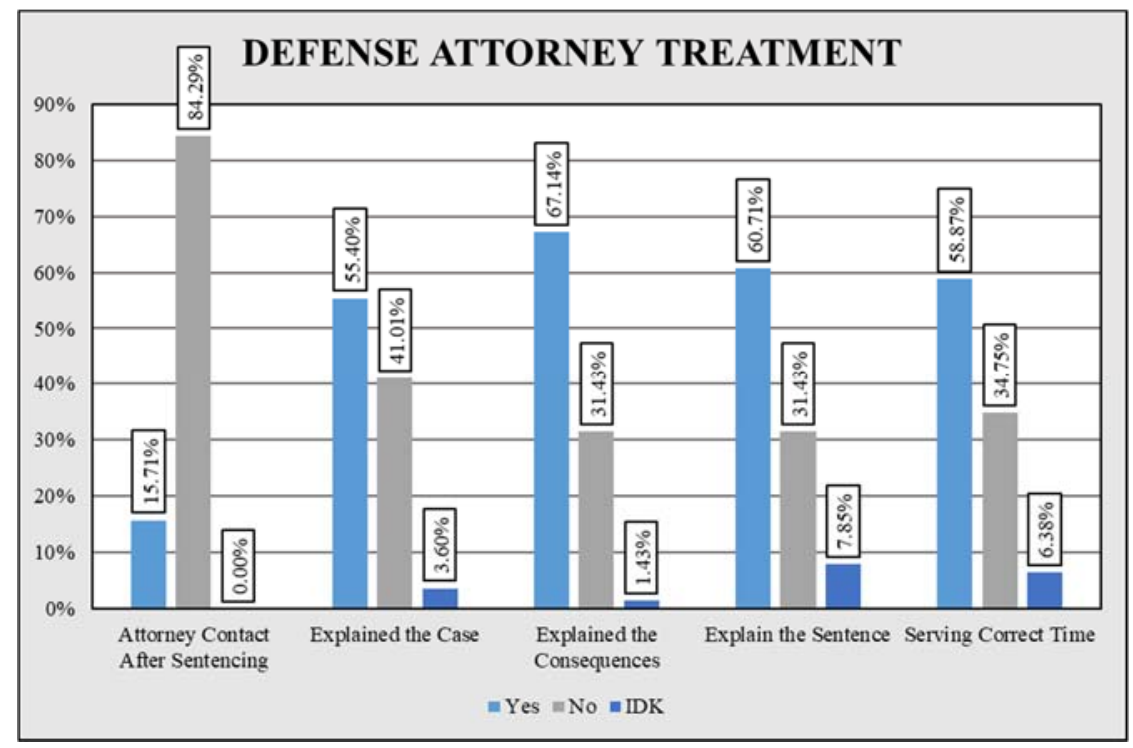


attorney. Only $0.72 \%$ said they didn't know if they had a public or private defender, therefore, it was excluded from the graph above.

The majority responded that the attorney's did not contact them again after sentencing $(84.29 \%)$ while only $15.71 \%$ remained in contact. When asked if the attorney explained the case in a way they could understand $55.40 \%$ said yes, $41.01 \%$ said no, and 3.60\% said I don't know. Additionally, the survey asked if the attorney explained the consequences of a conviction, the majority said yes (67.14\%) with $31.43 \%$ stating no, and $1.43 \%$ didn't know. Then, it was asked if the sentence was explained to them, $60.71 \%$ said yes, $31.43 \%$ said no, and $7.85 \%$ said I don't know. Last, they were asked if they were serving their time as they would as told by their attorney and the majority said yes (58.87\%), 34.75\% said no, and 6.38\% said I don't know.

\section{Plea Deal}

Table 6.1: Plea Deal

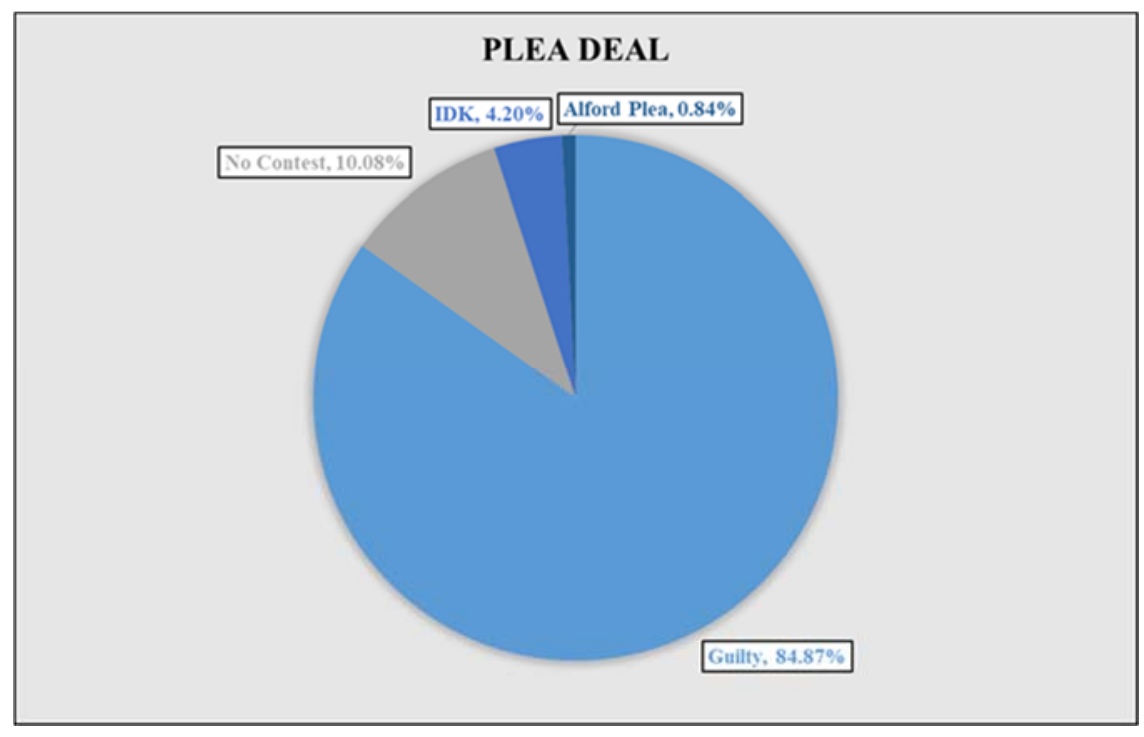

Of the respondents who did not go to trial, $84.87 \%$ plead guilty, $10.08 \%$ plead no contest, 4.20\% didn't know, and $0.84 \%$ took an Alford plea ("An Alford plea is a guilty plea in which the defendant does not admit commission of the criminal act or asserts that he is innocent. In such a 
situation, the trial court must determine that there is a factual basis for the plea" (Oregon Judicial Department, 2008). $84.51 \%$ took a plea deal and $14.49 \%$ went to a trial.

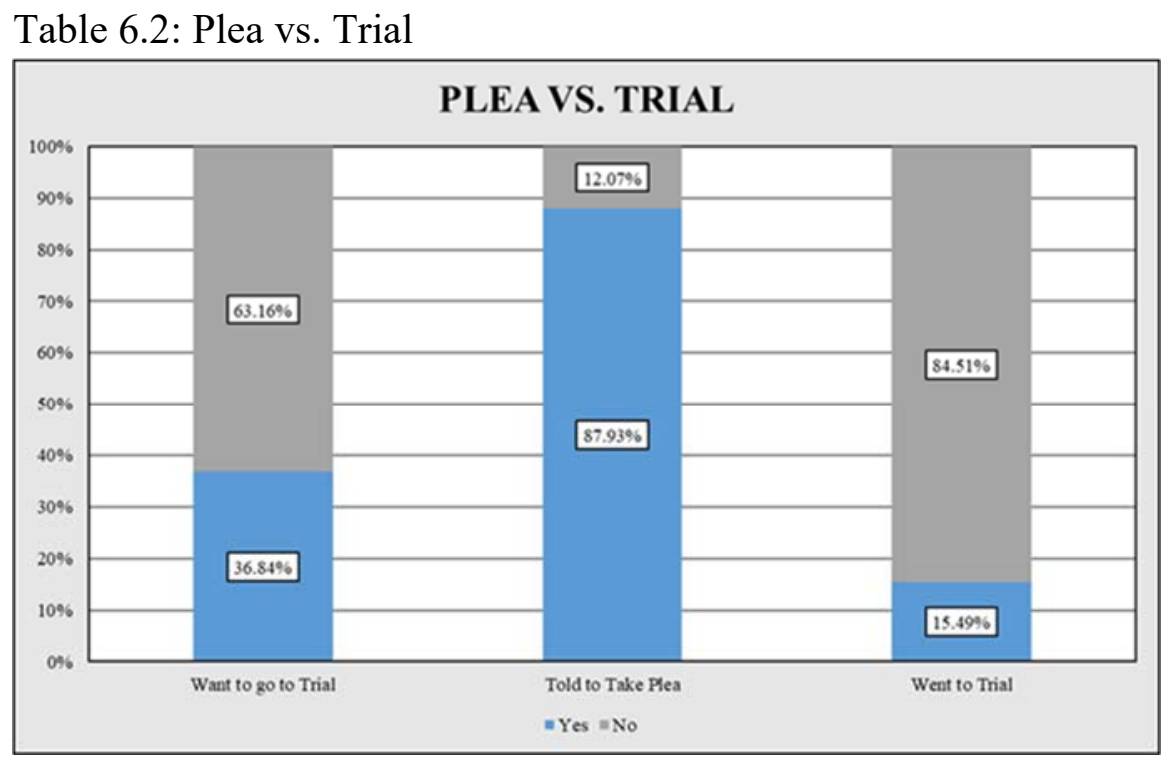

Showcased in Table 6.2, of the respondents that took a plea deal, $87.93 \%$ were told to take the plea while $12.07 \%$ were not told. Most of the survey takers answered that they did not want to go to trial (63.16), however, $36.84 \%$ wanted to go to trial.

Table 6.3: Understand Plea Deal

\begin{tabular}{|l|c|c|c|}
\hline \multicolumn{4}{|c|}{ UNDERSTANDING THE PLEA DEAL } \\
\hline & Yes & No & IDK \\
\hline Explain the Plea & $66.39 \%$ & $15.13 \%$ & $18.49 \%$ \\
Explain the Consequences & $63.03 \%$ & $21.01 \%$ & $15.97 \%$ \\
Explained Withdrawl of Plea & $16.24 \%$ & $70.09 \%$ & $13.68 \%$ \\
Understood the Plea & $61.54 \%$ & $25.64 \%$ & $12.82 \%$ \\
Judge Ask Your Understanding & $90.60 \%$ & $0.85 \%$ & $8.55 \%$ \\
Told Judge I Understood Plea & $95.15 \%$ & $1.94 \%$ & $2.91 \%$ \\
Fullfillment of Plea & $19.83 \%$ & $56.03 \%$ & $24.14 \%$ \\
\hline
\end{tabular}


When the survey asked Did your attorney go over a written plea petition with you? $66.39 \%$ responded yes, $15.13 \%$ responded no, and $18.49 \%$ said they didn't know. Then, it was asked if the attorney explained the consequences of the plea agreement, $63.03 \%$ said yes, $21.01 \%$ said no and $15.97 \%$ said they didn't know. The majority responded when asked Were you told that you could withdraw your plea? With no (70.09)\%, followed by yes (16.24\%), and 13.68\% said I don't know. They were then asked if they understood the plea and the majority said yes (61.54\%), 25.64\% said no, and 12.82\% said I don't know. Last, Are you serving your time as you were told that you would by your attorney? (i.e. able to be in specific programs, good time, get specific jobs, etc.) $56.03 \%$ said no they are not serving their time as they were told, $19.83 \%$ said yes, and $24.14 \%$ said I don't know.

\section{Sentence}

Table 7.1: Fairness/Error Sentence

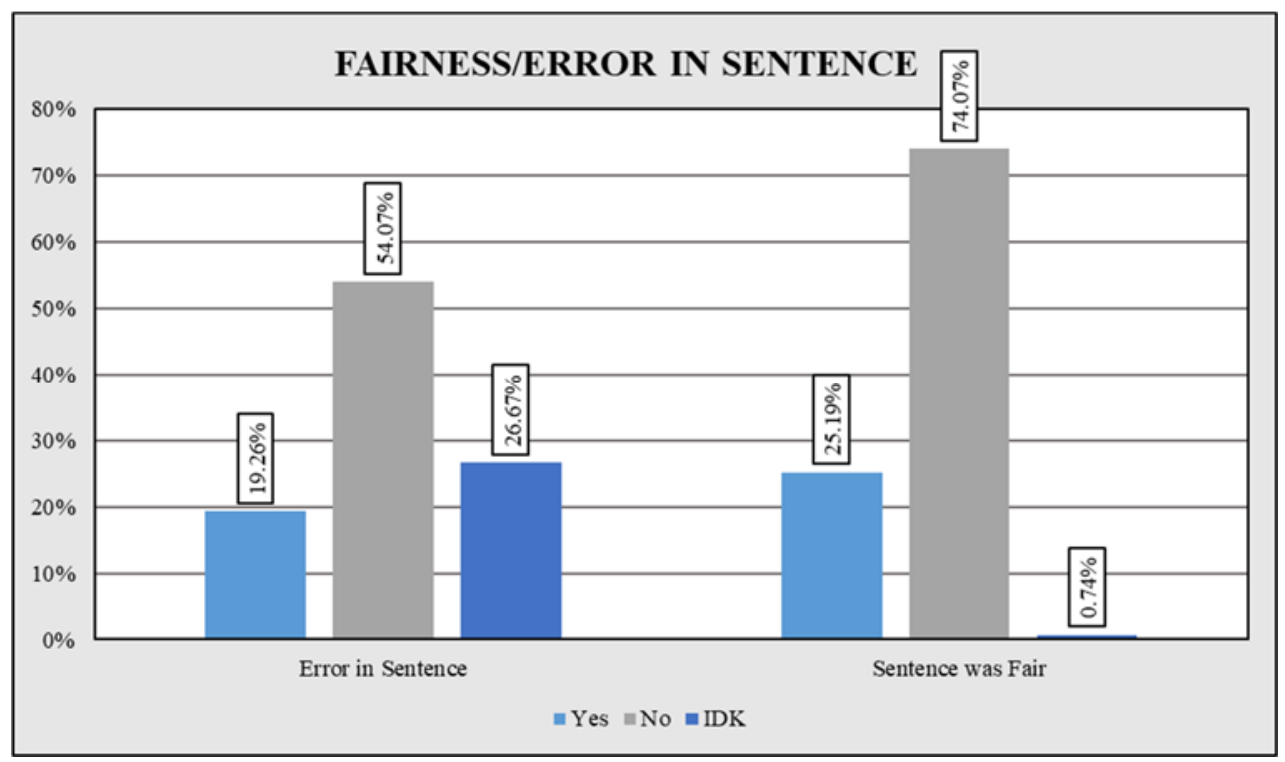

When asked when the first time they saw their sentence/judgement, the majority response stated "at sentencing". This was following by "in prison" (25.90\%), while 9.35\% "never saw it", 
9.35\% didn't know when they first saw their sentence, and 5.76\% selected other. The responses to other were "meeting with attorney" and "when I appealed it to the parol[sic] board". The survey then asked if the respondents felt there was an error in their sentence $54.07 \%$ said no, $19.26 \%$ said yes, and $26.67 \%$ said I don't know. Then it was asked if they felt their sentence was fair, 74.07\% said no, 25.19\% said yes, and 0.74\% answered I don't know.

\section{Discussion}

\section{Do you think your sentence is fair?}

Procedural justice aims to treat everyone under the guise of the criminal justice system with respect and understanding. It was important to this study to ask questions that allowed the women to share their stories and to talk about their direct contact with agents of the system. There is one question that is especially important to the research: Do you think your sentence was fair? This question was compared using cross tabulation against all other quantitative questions in the survey. Using p-values of $.01, .05$, and .10 , it was found that there was a strong relationship between this question and other questions.

The first question about fairness of sentence showed that women who didn't receive their bail money back were more likely to answer that their sentence wasn't fair. When defendants post bail, if they return to their trial, they are supposed to receive their bail back. When a defendant doesn't receive their money back, they feel their sentence isn't fair because the process isn't fair. This comparison showed an asymptotic significance of .000 . The next question that had an asymptotic significance of .000 was if they were under the influence when questioned. The women who answered that they were under the influence of drugs/alcohol when questioned by police were more likely to answer that the sentence wasn't fair. 
Table 7.1: Fair Sentence

\begin{tabular}{|c|c|}
\hline \multicolumn{2}{|c|}{ DO YOU THINK YOUR SENTENCE IS FAIR? } \\
\hline Sentence Fair & Asymptotic Significance (2-sided) \\
\hline \multicolumn{2}{|c|}{ P-Value $\leq .01$} \\
\hline *Received Bail Back & 0.000 \\
\hline *Under Influence When Questioned & 0.000 \\
\hline \multicolumn{2}{|c|}{ P-Value $\leq .05$} \\
\hline *Know Cops & 0.013 \\
\hline *Attorney Explained Case & 0.017 \\
\hline *Know Withdraw Plea & 0.025 \\
\hline *Forced to Talk & 0.039 \\
\hline *Appeal Deadline & 0.047 \\
\hline *Error in Sentence & 0.050 \\
\hline \multicolumn{2}{|c|}{$\mathrm{P}-$ Value $\leq .10$} \\
\hline${ }^{*}$ Argue Against Release & 0.052 \\
\hline *Understand Plea & 0.053 \\
\hline *Not Do Plea & 0.055 \\
\hline *Attorney Explained Sentence & 0.059 \\
\hline *Want to Go to Trial & 0.068 \\
\hline${ }^{*}$ Co-Defendents & 0.078 \\
\hline *Probation at Arrest & 0.073 \\
\hline *Bail to Restitution & 0.084 \\
\hline *Explain Consequence Plea & 0.090 \\
\hline
\end{tabular}

The first question of bail points to that the courts failed them by not promising to return their money when that was the procedure to do so and the second question reveals that the women feel they were unfairly questioned by the police and that them being under the influence impacted their judgement. The police, if following proper procedure, should've allowed the defendant to become sober before pressuring them further. Since this was not procedurally just, the women found that this wasn't fair to them.

The next strongest relationship was whether the women knew the cops that were arresting them (.013). If the women knew the officers arresting them, they were more likely to answer their process was fair while they were more likely to answer that the process wasn't fair when they didn't know the arresting officers. If the attorney explained the case in a way the women could understand they were more likely to think the sentence was fair, if they did not understand the case in a way that they could understand, they were likely to answer that the answer wasn't 
fair. As mentioned in the literature review, public defenders tend to take on large caseloads. The sample of women showed that $90.65 \%$ of the women had public defenders versus privately retained lawyers.

If the women knew they could've withdrawn their plea, they were more likely to answer that their sentence was fair. If the women didn't know they could withdraw their plea, they answered that the sentence wasn't fair (.025). Going back to the treatment from law enforcement officials, if the women felt as though they were forced to talk when being questioned, they felt their sentence wasn't fair. The questioned about if they knew about their deadline to appeal was compared and found a relationship of .047 (just under the .05 p-value, above this value, the relationship starts to weaken and therefore those will not be discussed in this paper). If they didn't know the deadline to appeal (not explained or did not understand) the women felt their sentence was unfair. Last, if they felt there was an error in their sentence, they did not think their sentence was fair. It is important to note the difference between these questions, an error would mean that they were not charged correctly, or they did not receive all or parts of the plea deal while unfairness would mean they didn’t deserve the sentence they received or possibly they didn't understand why they received the sentence they did.

Do you think your sentence was fair? was analyzed for the purpose of showing relationships between how they answered other questions and how that affected their answer to this question. The other questions essential asked "Where you being treated fairly?" and "Do you understand the process?". It is important because the theory of procedural justice argues that if the system is giving procedurally just treatment, the offenders (women prisoners) will be more likely to feel that the process is fair, they will be more likely to trust the system which legitimizes it. This will then lead to lowered rates of recidivism. Not all answers posed a strong 
correlation; however, the questions that did tell a story. Not receiving bail back, which should be a part of the procedure, allows them to feel as though they weren't being respected by the courts. When they were under the influence of alcohol and being questioned, it felt like mistreatment from the police because they weren't in the right state of mind to answer the questions asked of them. This can lead to feelings of resentment toward the police which in turn leads to resentment of the system; thus, illegitimating it. When the case wasn't being explained to them in a way they could understand, it doesn't allow them a voice in their process, makes them believe their attorney isn't accurately representing them, and then they don't feel their sentence was fair because they didn't understand why they were being sentence in the first place. Therefore, causing them to have mistrust with lawyers, courts, and the police.

\section{Limitations}

The limitations of this study are that the population was not randomly selected, and the sample size was small. The women prisoners were chosen as a specific population for the study. This means that it cannot be generalized beyond prisoners and even more specifically, past prisoners in Oregon. Additionally, women may have different experiences than men in the criminal justice system. Since there is no comparative study in Oregon of the perceptions of men prisoners on procedural justice it cannot explain the experiences of men versus women.

\section{Conclusion}

Women Prisoners in CCCF shared their story to enable us to study their experience in the criminal justice system. With their valuable information, it allowed us the opportunity to discover that they are not receiving procedurally just treatment. The findings showcase that because of the treatment from police, defense attorneys, and courts, they feel as though their 
sentence isn't fair. When they believe that their sentence isn't fair, it only further illegitimates the system and the laws that they are supposed to obey. It is important to note that treatment of them isn't bad overall, but with this information, it can be used to fix the areas that needs improvement when it comes to procedurally just treatment. If some of these experiences can be turned into positive ones, maybe it'll lead to feelings of legitimacy and fairness.

It is recommended that further inquiry is needed in order to fully assess the problems being experienced. However, minor improvements can be made in order to increase the feelings of fairness and possibility reduce recidivism rates. One suggestion is reminding clients of deadlines and giving them the ability to withdraw pleas would further substantiate their feelings of fairness and legitimacy. Furthermore, the police need to reduce the amount of questioning they do while the suspect is under the influence and not use unnecessary force in order to get them to talk. Additionally, the courts need to either eliminate bail all together or find a way of fixing the current system in place. The survey suggests that if they aren't receiving their bail back, even if they appeared at court, they are less likely to find their sentence fair. Finally, it would be beneficial for defense attorneys to walk through the cases with their clients, make sure they understand what is going on. If they understand what is going on, they are being treated respectfully and fairly, then there is a possibility that they will find the Oregon criminal justice system legitimate and obey the law. 


\section{References}

Bibas, S. (2004). Plea Bargaining outside the Shadow of Trial. Harvard Law Review, 117(8), 2463-2547. Retrieved from https://www.jstor.org/.

Boppre, B.L. (2018). Intersections Between Gender, Race, and Justice-Involvement: A Mixed Methods Analysis of Women's Experiences in the Oregon Criminal Justice System. (Unpublished doctoral dissertation). University of Nevada Las Vegas, Las Vegas, Nevada.

Bottoms, A., Tankebe, J. (2012) Beyond Procedural Justice: A Dialogic Approach To Legitimacy In Criminal Justice. The Journal of Criminal Law and Criminology (1973-), 102(1), 119-170.

Butler, A.M. (1997). Gendered Justice in the American West: Women Prisoners in Men's Penitentiaries / Edition 1. University of Illinois Press.

Casey, S.N., Wilson, J.C. (1998). Discretion, disparity or discrepancy? A review of sentencing consistency. Psychiatry, Psychology and Law, 5(2), 237-247. Retrieved from https://www.tandfonline.com/.

Casper, J.D., Tyler, T., Fisher, B. (1988). Procedural Justice in Felony Cases. Law \& Society Review, 22(3), 483-508. Retrieved from https://www.jstor.org/.

Coffee Creek Correctional intake process. Oregon Prison Resources. Retrieved from https://www.oregonprisonresearch.wordpress.com/inmate-information/.

Daly, K., Tonry, M. (1997). Gender, Race, and Sentencing. Crime and Justice, 22, 201-252. Retrieved from https://www.journals.uchicago.edu/.

Denson, B. (2014, October 9). Going to prison in Oregon: New inmates start at 'dirty side' of Coffee Creek. The Oregonian. Retrieved from https://www.oregonlive.com. 
Druckman, D., Wagner, L.M. (2015). Justice and Negotiation. Annual Review of Psychology, 67, 387-413. Retrieved from, https://www.annualreviews.org/ .

Ellis, C.G., (2005). Female inmates perspectives on incarceration and correctional education at Coffee Creek Correctional Facility. (Doctoral dissertation). Retrieved from https://pdxscholar.library.pdx.edu/.

Feeley, M.M., Rubin, E.L. (1998). Judicial Policy Making and the Modern State: How the Courts Reformed America's Prisons. Cambridge, UK: Cambridge University Press.

Green, B.A. (2003). Criminal Neglect: Indigent Defense From a Legal Ethics Perspective. Emory Law Journal, 52, 1169-1199. Retrieved from https://heinonline.org/HOL/LandingPage?handle=hein.journals/emlj52\&div=39\&id=\&pa $\mathrm{ge}=\& \mathrm{t}=1557732538$.

Hagan, J. Hans, V. (2017). Procedural Justice Theory and Public Policy: An Exchange. Annual Review of Law and Social Science, 13(1-3). Retrieved from https://www.annualreviews.org/.

Heumann, M. (1977). Plea Bargaining: The Experiences of Prosecutors, Judges, and Defense Attorneys. Chicago, IL: The University of Chicago Press.

Jackson, J., Bradford, B., Hough, M., Myhill, A., Quinton, P., Tyler, T.R. (2012). Why Do People Comply With the Law?: Legitimacy and the Influence of Legal Institutions. British Journal of Criminology, 52(6), 1051-1071. Retrieved from http://web.b.ebscohost.com/.

Nagin, D.S., Telep, C.W. (2017). Procedural Justice and Legal Compliance. Annual Review of Law and Social Science, 13(5-28). Retrieved from https://www.annualreviews.org/.

ODOC Intake \& Assessment. DOC Offender Management \& Rehabilitation. Retrieved from 


\section{https://www.oregon.gov/doc/OMR.}

Oregon Inmate Handbook-Coffee Creek Correctional Facility. Retrieved from https://www.law.umich.edu.

Oregon Judicial Department. (2008). Model Script for Accepting a Guilty or No Contest Plea.

Retrieved from

https://www.courts.oregon.gov/programs/interpreters/wantto.../uniformpleascript.pdf

Pickett, J.T. (2018). Public Opinion and Criminal Justice Policy: Theory and Research. Annual Review of Criminology, 2. Retrieved from https://www.annualreviews.org/.

Poythress, N.G., Petrila, J., McGaha, A., Boothroyd, R. (2002). Perceived coercion and procedural justice in the Boward mental health court. International Journal of Law and Pschiatry, 25. 517-533. Retrieved from https://www.ncbi.nlm.nih.gov/pubmed/.

Scissors, B., Lundell, A. (2016, September). Women in Prison in Oregon. Oregon Justice Resource Center. Retrieved from https://ojrc.info/.

Sklansky, D.A. (2018). The Problems With Prosecutors. The Annual Review of Criminology, 1, 451-469. Retrieved from https://www.annualreviews.org/.

Sparks, R., Bottoms, A.E., Hay, W. (1996). Prisons and the problem of order. Oxford, England: New York Clarendon Press.

Steffensmeier, D., Kramer, J., Streifel, C. (1993). Gender and Imprisonment Decisions. Criminology, 31(3), 411-446. Retrieved from http://www.onlinelibrary.wiley.com/.

Steffensmeier, D., Ulmer, J., Kramer, J. (2006). The Interaction of Race, Gender, and Age in Criminal Sentencing: The Punishment Cost of Being Young, Black, and Male.

Criminology, 36(4), 711-898. Retrieved from https://www.onlinelibrary.wiley.com/. 
Stuntz, W.J. (2004). Plea Bargaining and Criminal Law’s Disappearing Shadow. Harvard Law Review, 117(8), 2548-2569. Retrieved from https://www.jstor.org/.

Terry, L. (2016, February 1). How Much Does Oregon Spend on Prisons?. Retrieved from https://www.newsmax.com/.

Tyler, T.R. (2006). Why People Obey the Law. Princeton, New Jersey: Princeton University Press.

Tyler, T.R., Blader, S. (2000). Cooperation in Groups: Procedural Justice, Social Identity, and Behavioral Engagement. New York, NY: Routledge.

United States Census Bureau. (2018). QuickFacts Oregon. Retrieved from https://www.census.gov/quickfacts/or.

Visher, C.A., Travis, J. (2003). Transitions from Prison to Community: Understanding Individual Pathways. Annual Review of Sociology, 29(89-113). Retrieved from https://www.annualreviews.org/.

Wales, H.W., Hiday, V.A., Ray, B. (2010). Procedural justice and the mental health court judge's role in reducing recidivism. International Journal of Law and Psychiatry, 33(4), 265-271. Retrieved from https://www.ncbi.nlm.nih.gov/pubmed/.

Woodworth, W. (2017, February 16) Oregon faces skyrocketing female prison population. Statesman Journal. Retrieved from https://www.statesmanjournal.com/. 